\title{
Estrogen suppresses SOX9 and activates markers of female development in a human testis-derived cell line
}

\author{
Melanie K. Stewart, Deidre M. Mattiske and Andrew J. Pask ${ }^{*}$ (i)
}

\begin{abstract}
Background: The increasing incidence of reproductive disorders in humans has been attributed to in utero exposure to estrogenic endocrine disruptors. In particular, exposure of the developing testis to exogenous estrogen can negatively impact male reproductive health. To determine how estrogens impact human gonad function, we treated the human testis-derived cell line NT2/D1 with estrogen and examined its impact on SOX9 and the expression of key markers of granulosa (ovarian) and Sertoli (testicular) cell development.

Results: Estrogen successfully activated its cognate receptor (estrogen receptor alpha; ESR1) in NT2/D1 cells. We observed a significant increase in cytoplasmic SOX9 following estrogen treatment. After $48 \mathrm{~h}$ of estrogen exposure, mRNA levels of the key Sertoli cell genes SOX9, SRY, AMH, FGF9 and PTGDS were significantly reduced. This was followed by a significant increase in mRNA levels for the key granulosa cell genes FOXL2 and WNT4 after $96 \mathrm{~h}$ of estrogen exposure.

Conclusions: These results are consistent with estrogen's effects on marsupial gonads and show that estrogen has a highly conserved impact on gonadal cell fate decisions that has existed in mammals for over 160 million years. This effect of estrogen presents as a potential mechanism contributing to the significant decrease in male fertility and reproductive health reported over recent decades. Given our widespread exposure to estrogenic endocrine disruptors, their effects on SOX9 and Sertoli cell determination could have considerable impact on the adult testis.
\end{abstract}

Keywords: Estrogen, Sertoli cells, Testis, Sex determination

\section{Background}

Differences of sexual development (DSDs) are currently some of the most common birth defects in humans and often affect gonadal development and fertility. DSDs occur in 1:200-1:300 live births [1] and are increasing in incidence $[2,3]$. In Western countries in particular, DSDs continue to rise while sperm counts have decreased by more than $50 \%$ in the last 40 years [4]. This sharp decline in male reproductive health is of major

\footnotetext{
*Correspondence: ajpask@unimelb.edu.au

School of BioSciences, The University of Melbourne, Parkville, VIC 3010, Australia
}

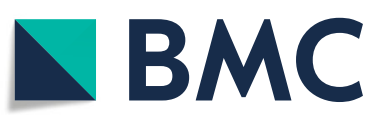

(C) The Author(s). 2020 Open Access This article is licensed under a Creative Commons Attribution 4.0 International License, which permits use, sharing, adaptation, distribution and reproduction in any medium or format, as long as you give appropriate credit to the original author(s) and the source, provide a link to the Creative Commons licence, and indicate if changes were made. The images or other third party material in this article are included in the article's Creative Commons licence, unless indicated otherwise in a credit line to the material. If material is not included in the article's Creative Commons licence and your intended use is not permitted by statutory regulation or exceeds the permitted use, you will need to obtain permission directly from the copyright holder. To view a copy of this licence, visit http://creativecommons.org/licenses/by/4.0/ The Creative Commons Public Domain Dedication waiver (http://creativecommons.org/publicdomain/zero/1.0/) applies to the data made available in this article, unless otherwise stated in a credit line to the data. concern and there is an urgent need to identify and

Although infertility and DSDs can have genetic causes, the recent and rapid decline in overall reproductive health and fertility is now unequivocally linked to our exposure to endocrine disrupting chemicals (EDCs) [5-10]. Estrogenic EDCs are some of the most pervasive in our environment and include compounds such as bisphenol A, $17 \alpha$-ethynylestradiol, phthalates, and genistein. These EDCs are capable of interacting with estrogen receptors to trigger ectopic activation of estrogen responsive signaling pathways [11]. Elevated estrogen levels are known to negatively impact the adult testis, leading to infertility [12]. Furthermore, estrogen signaling is imperative during fetal understand potential contributors to this issue. 
development, where the correct balance of androgens and estrogens is required for sexual differentiation of both the male and female reproductive tracts [13-15].

The role of estrogen in directing vertebrate gonad development has been well studied. In non-mammalian vertebrates, estrogen plays a fundamental role in actively directing the indifferent gonad towards an ovarian fate [16]. Estrogen is also essential for gonad differentiation in many mammalian vertebrates, such as in goats [17], sheep [18, 19], and cows [20], where production of the enzyme aromatase promotes the synthesis of estrogen from testosterone in the fetal ovary. In marsupials, exposure of embryonic XY gonads to exogenous estrogen before sex determination results in complete ovarian formation in the opossum [21], and tammar wallaby [22], demonstrating the ability of the hormone to promote ovarian fate despite genetic predisposition to form a testis.

Estrogen receptors (ERs) are expressed in the indifferent somatic cells of the fetal gonad in all mammals and are targets of estrogen during critical periods of development [23-25]. The human XX indifferent gonad produces estrogen before ovarian differentiation [26], suggesting it may have a function in driving ovarian development.

In contrast, estrogen is not thought to play a direct role in mouse fetal ovarian formation as deletion of ERs or aromatase (encoded by Cyp19) does not affect early ovarian differentiation $[27,28]$. Shortly after birth, somatic cells in ER- or Cyp19-deficient ovaries upregulate Sox 9 and take on Sertoli cell morphology, demonstrating estrogen signaling is required for granulosa cell and ovarian maintenance in mice. When exogenous estrogen is administered, these 'Sertoli-like' cells downregulate Sox9 and granulosa cell fate is rescued [27, 28]. Thus, in rodents, estrogen plays a central role in maintaining granulosa cell fate and repressing key testis factors such as Sox9.

Sox9 is both necessary and sufficient to drive testicular development [29]. Prior to embryonic day (E) 11.5 in mice, SOX9 is present in the cytoplasm of somatic cells in the gonads of both sexes [30]. At E11.5, when Sry reaches a peak in expression in XY embryos, SOX9 is rapidly translocated to the nucleus where it triggers a cascade of transcriptional events leading to testis determination. Specifically, it upregulates expression of itself and the key testis genes, Amh, Fgf9, and Ptgds, among others [31].

In females, the absence of Sry leads to the disappearance of the cytoplasmic pool of SOX9 and transcription of Sox 9 ceases. This allows for the stabilisation of $\beta$-catenin, which is essential for ovarian formation [32] and expression of the ovarian genes Foxl2 and Wnt4. Wnt4 is present in both XX and XY gonads at E11.0 but is downregulated in males at E11.5 [33]. Foxl2 is necessary for maintenance of granulosa cell fate and its ablation in mouse ovaries leads to transdifferentiation of granulosa cells to a Sertoli cell phenotype with upregulation of Sox9 [34]. FOXL2, in conjunction with activated estrogen receptors, is proposed to maintain granulosa cell fate by suppressing Sox9 transcription. This demonstrates the plasticity of these cells and the 'push-and-pull' between testis and ovarian markers, which can be mediated in part by estrogen. Furthermore, these studies illustrate that the translocation of SOX9 into the nucleus is a critical step for the formation of a testis and repression of ovarian development.

In marsupials, estrogen can impact two of the fundamental transcription factors in regulating gonadal cell fate decisions: SOX9 and FOXL2 [34, 35]. Exogenous estrogen suppresses SOX9 by trapping it in the cytoplasm of somatic cells. This prevents upregulation of male specific pathways and induces expression of FOXL2, indicative of granulosa cell fate [35]. In humans, nuclear SOX9 is similarly required for male development and mutations that affect SOX9 nuclear import result in DSDs [36-38]. However, it is unknown if estrogen can impact the subcellular localisation of SOX9 in humans. In the present study, we exposed the human testis-derived cell line NT2/D1 to estrogen and examined its impact on the subcellular localisation of SOX9.

\section{Results}

Estrogen activates estrogen receptor $a$ in NT2/D1 cells

Estrogen receptor $\alpha(E R \alpha)$ was translocated to the nucleus at both concentrations of EE2 after $48 \mathrm{~h}$. In comparison, in control cultures ER $\alpha$ remained largely cytoplasmic (Fig. 1). Nuclear localisation indicates the activation of ER $\alpha$ in the presence of both 10 and 100 $\mathrm{nM}$ of EE2 in our culture system and confirms the ability of the NT2/D1 cells to respond to estrogen exposures.

\section{Activated ERa increases cytoplasmic SOX9 levels}

SOX9 was primarily nuclear in control cultures of NT2/ D1 cells, with a small proportion of cytoplasmic SOX9. SOX9 was still present in the nucleus in all estrogen treated cells, however, there was an increase in the amount of SOX9 in the cytoplasm after 48 (Fig. 2) and 96 h (Fig. 3) of culture. This was quantified by colocalisation analyses and shown in Fig. 4 (48 h: 10 nM EE2, $P<0.0001$; 100 nM EE2, $P<0.0001 ; 96$ h:10 nM EE2, $P=0.001 ; 100$ nM EE2, $P<0.001)$. There were no significant differences in the amount of cytoplasmic SOX9 between estrogen concentrations ( $48 \mathrm{~h}: P=0.37 ; 96 \mathrm{~h}: P=0.41$ ) or duration of treatment (10 nM, $P=0.26 ; 100 \mathrm{nM}: P=0.75$ ). 


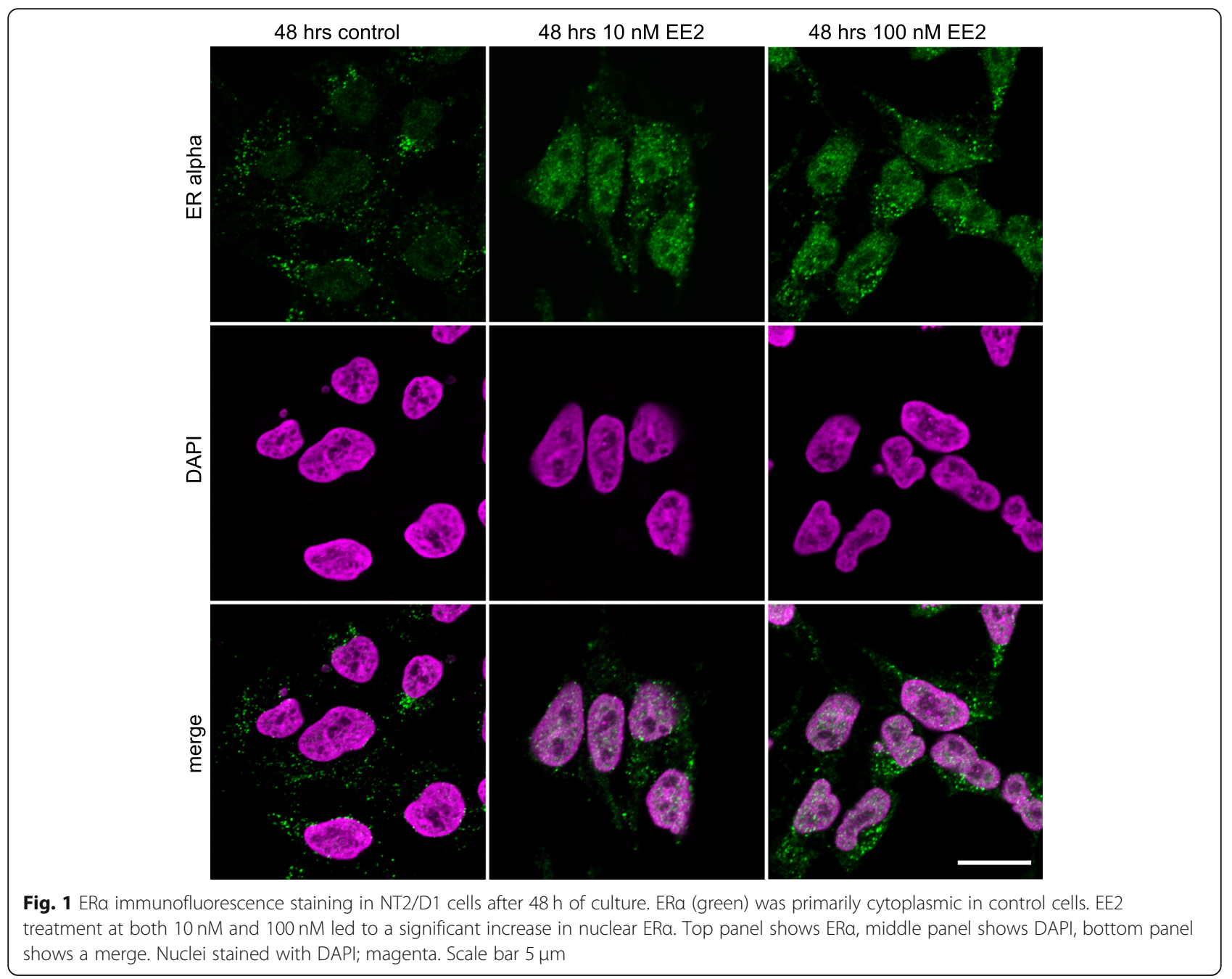

\section{Estrogen suppresses testis markers after $48 \mathrm{~h}$}

Estrogen treatment of NT2/D1 cells for $48 \mathrm{~h}(n=10 \mathrm{cul}-$ tures) reduced the mRNA levels of key testicular genes (Fig. 5a). The lower concentration of $10 \mathrm{nM}$ of EE2 caused a significant reduction in mRNA levels of SOX9 $(P<0.001), S R Y(P=0.04), A M H(P<0.001)$ and $F G F 9$ $(P<0.001)$. PTGDS expression was also suppressed, but this was not significant $(P=0.1)$. One hundred $\mathrm{nM}$ of EE2 significantly reduced mRNA levels of SOX9 $(P=$ $0.016), \operatorname{SRY}(P<0.001), A M H(P<0.001)$, FGF9 $(P=$ $0.002)$, and $P T G D S(P<0.001)$.

\section{Estrogen promotes female markers after $96 \mathrm{~h}$}

Prolonged estrogen treatment for $96 \mathrm{~h}$ ( $n=5$ cultures) led to activation of key ovarian genes (Fig. 5b). Cells treated with $10 \mathrm{~nm}$ of EE2 had an increase in mRNA levels of WNT4, however this was not significant $(P=$ 0.06). FOXL2 expression remained unchanged at this concentration. However, treatment with $100 \mathrm{~nm}$ of EE2 significantly increased the mRNA levels of FOXL2 $(P=$ $0.01)$ and WNT4 $(P=0.04)$. Despite being significantly suppressed at $48 \mathrm{~h}$, the male markers SRY, SOX9 and $A M H$ showed no significant suppression following $96 \mathrm{~h}$ of estrogen exposure (Fig. 5b).

\section{Discussion}

Estrogen plays a critical role in sex determination and early sexual differentiation in all non-mammalian vertebrates [39]. However, the impact of estrogen on these processes in mammals has remained less clear. In marsupials, exposure of the developing gonads to exogenous estrogen blocks SOX9 nuclear import and affects its function at both the gene and protein level [35]. The nuclear translocation of the transcription factor SOX9 is essential for Sertoli cell specification and the formation of a testis [40]. Indeed, mutations affecting its nuclear import significantly impact testis development and cause differences in sexual development (DSDs) in humans $[36,38]$. This study examined if exogenous estrogen could have an effect on SOX9 localisation in human cells potentially impacting its role to activate and maintain Sertoli cell fate. 


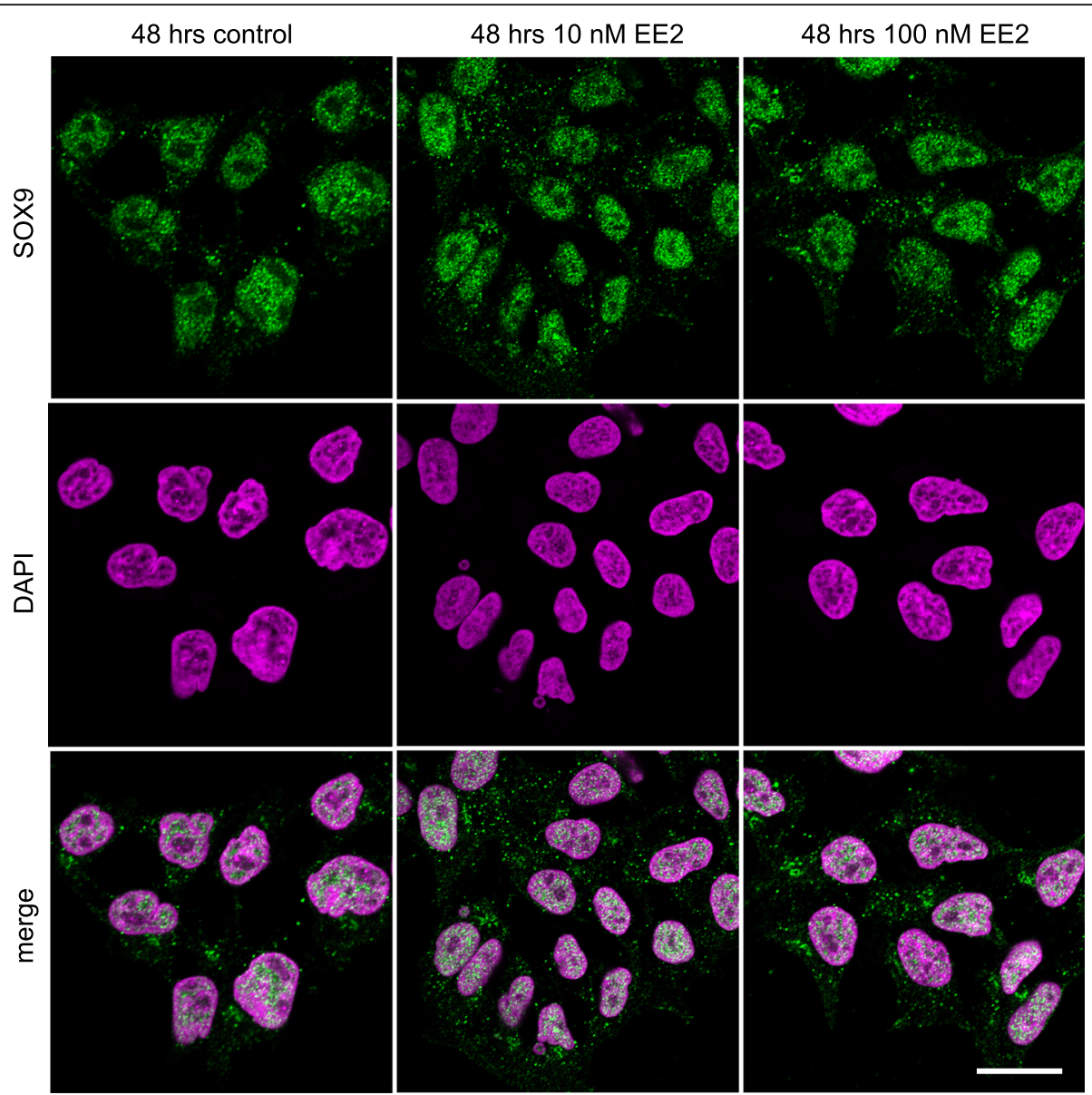

Fig. 2 SOX9 immunofluorescence staining in NT2/D1 cells after $48 \mathrm{~h}$ of culture. SOX9 (green) was primarily nuclear (nuclei marked by DAPl; magenta) in the control cells. EE2 treatment at both $10 \mathrm{nM}$ and $100 \mathrm{nM}$ led to a greater amount of SOX9 in the cytoplasm. Top panel shows SOX9, middle panel shows DAPI, bottom panel shows a merge. Scale bar $5 \mu \mathrm{m}$

We have used the human testis-derived cell line NT2/ D1 to investigate the impacts of exogenous estrogen on SOX9 localisation and the downstream changes to genes regulating testicular and ovarian fate. NT2/D1 cells display cellular characteristics of embryonic Sertoli cells and express the repertoire of genes observed in testis determination [41, 42]. They have been used in numerous previous studies to elucidate the molecular mechanisms involved in key gonad pathways, including the factors involved in SOX9 nuclear import [43, 44], SOX9 regulation of $A M H$ [45], regulation of SOX9 by PGD2 [46], interactions between SRY and $\beta$-catenin [47], mediators of SRY subcellular localisation [48], and the role of MAP3K1 in regulating gonadal pathways [49].

We observed a change in ER $\alpha$ distribution within NT2/D1 cells following estrogen exposures, with considerable accumulation in the nucleus. The nuclear localisation of ER $\alpha$ confirms its activation by estrogen [50]. This coincided with a significant accumulation of SOX9 in the cytoplasm of estrogen treated NT2/D1 cells, consistent with previous findings in marsupials [35]. Despite the accumulation of SOX9 in the cytoplasm, estrogen exposed cells still had some nuclear SOX9, but this was not sufficient to maintain the male development program after $48 \mathrm{~h}$ of estrogen treatment. Similarly, humans who are haploinsufficient for $S O X 9$ display male to female sex reversal despite having normal nuclear translocation of the protein [51], indicating that a threshold of SOX9 is required to activate the male development pathway.

Estrogen exposures caused a significant decrease in expression of the SOX9 target genes AMH, PTGDS and FGF9 after $48 \mathrm{~h}$. Nuclear SOX9 drives $A M H$ upregulation in the developing testis of humans [45] to trigger the regression of the Müllerian ducts, facilitating patterning of the male urogenital tract [52]. Prostaglandin $\mathrm{D}$ synthase (PTGDS) is another downstream target of SOX9 and produces prostaglandin D2 (PGD2) [53], which is continually required to provide sustained expression of SOX9 in the testis [54] and can induce nuclear import of SOX9 [44]. We also examined the impact of estrogen on FGF9, another key factor in 

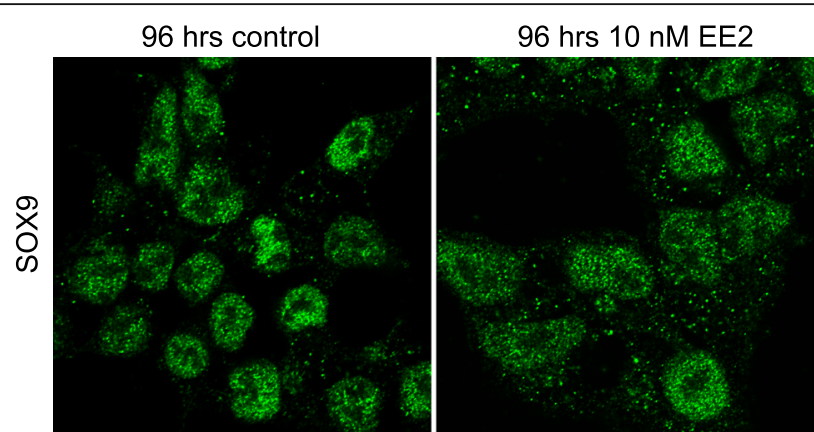

96 hrs 100 nM EE2
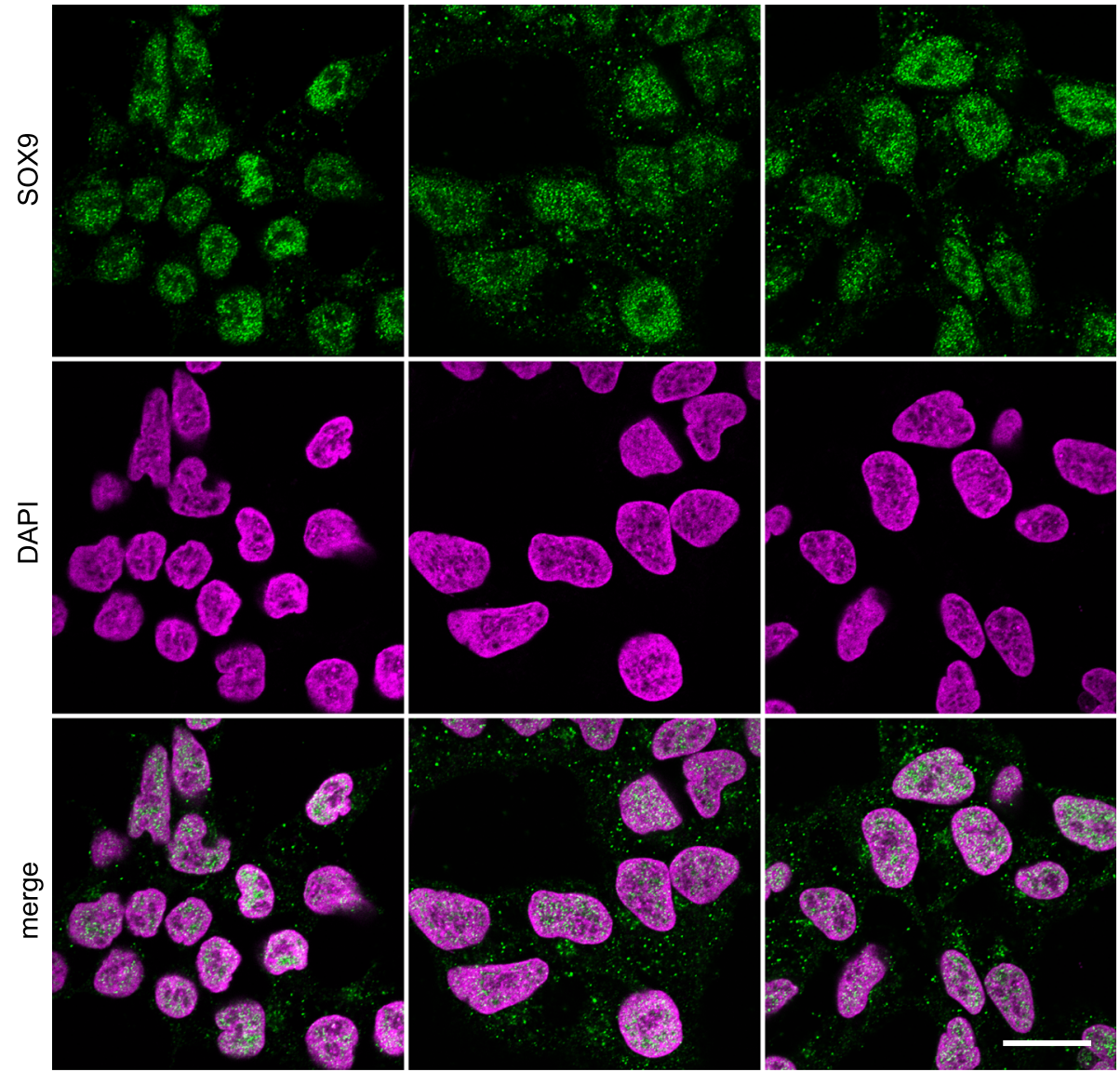

Fig. 3 SOX9 immunofluorescence staining in NT2/D1 cells after $96 \mathrm{~h}$ of culture. SOX9 (green) was primarily nuclear (nuclei marked by DAPI; magenta) in the control cells. EE2 treatment at both $10 \mathrm{nM}$ and $100 \mathrm{nM}$ led to a greater amount of SOX9 in the cytoplasm. Top panel shows SOX9, middle panel shows DAPI, bottom panel shows a merge. Scale bar $5 \mu \mathrm{m}$

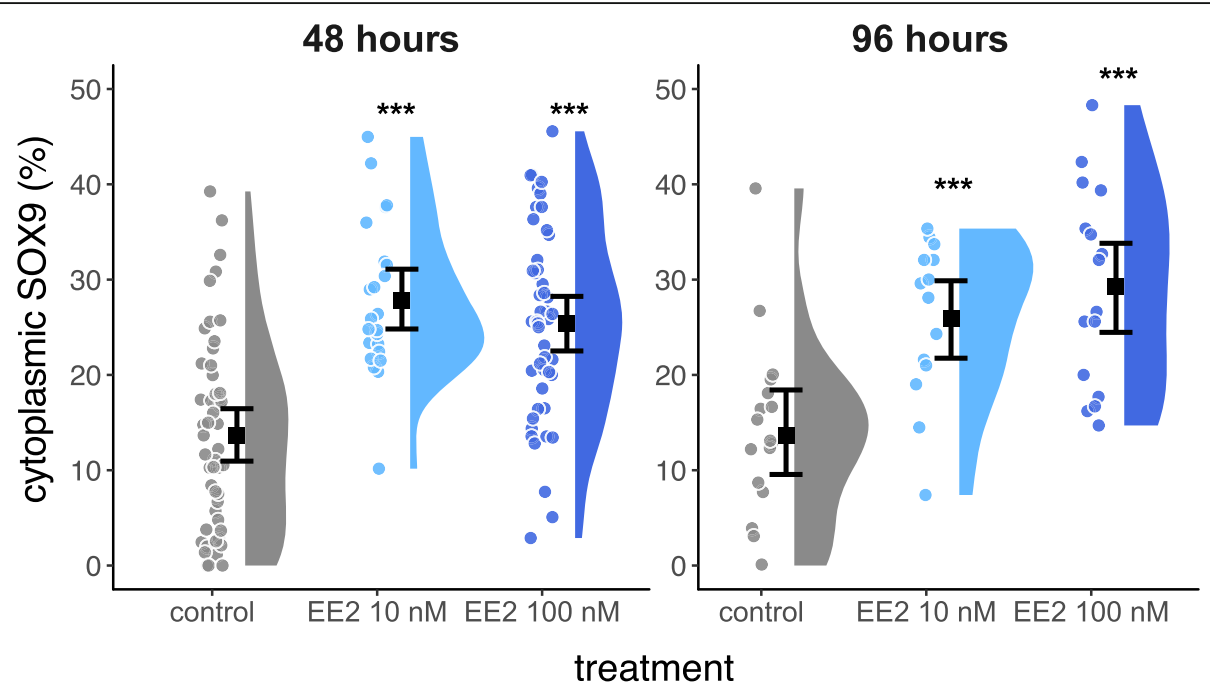

Fig. 4 Raincloud plot of the percentage of cytoplasmic SOX9 in NT2/D1 cells. Each filled circle indicates a data point. The error bars delineate the $95 \%$ confidence interval of the mean (black square). The density distribution is indicated by the filled area. The percentage of cytoplasmic SOX9 is significantly increased for all treatments (* indicates $P<0.05,{ }^{* *}$ indicates $P<0.01,{ }^{* *}$ indicates $P<0.001$ compared to the control) 


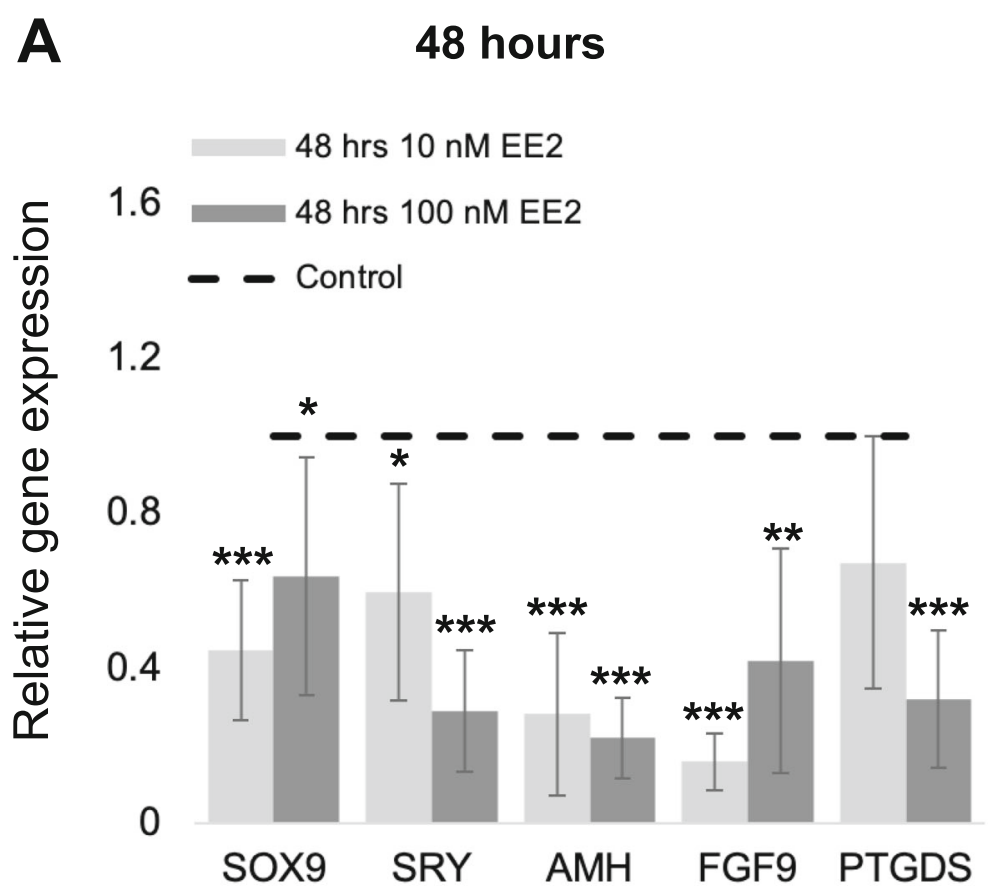

B

96 hours

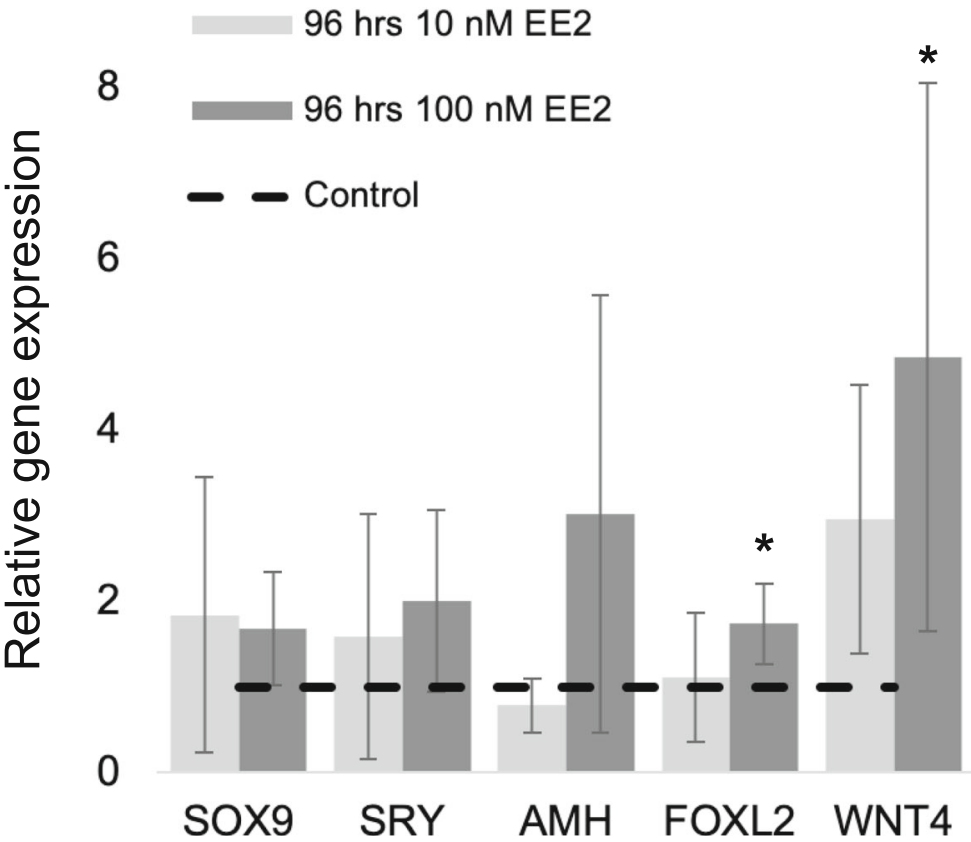

Fig. 5 Gene expression of key gonad markers in NT2/D1 cells. Quantitative mRNA levels of SOX9, SRY, AMH, FGF9 and PTGDS after $48 \mathrm{~h}$ (A; $n=10$ ) and SOX9, SRY, AMH, FOXL2 and WNT4 after $96 \mathrm{~h}(\mathrm{~B} ; n=5)$ with either $10 \mathrm{nM}$ or $100 \mathrm{nM}$ of EE2. Expression levels in control cells were designated as 1 and illustrated by the dotted line. Error bars show the $95 \%$ confidence interval of the mean. Expression of each gene in the corresponding estrogen treated culture was expressed relative to control levels. All testis markers had significantly reduced mRNA levels following $48 \mathrm{~h}$ of EE2 treatment (a). Testis markers did not show reduced mRNA levels after $96 \mathrm{~h}$, however the ovarian markers FOXL2 and WNT4 had significant increases in expression (b). ( ${ }^{*}$ indicates $P<0.05$, ${ }^{* *}$ indicates $P<0.01$, ${ }^{* *}$ indicates $P<0.001$ compared to the control) 
maintaining SOX9 expression and Sertoli cell differentiation in the developing testis [55]. Together, our results indicate that estrogen is able to impact the ability of SOX9 to activate the male developmental pathway in a human cell line.

Estrogen exposure also caused the induction of female marker genes, WNT4 and FOXL2 after $96 \mathrm{~h}$ of exposure. This is an identical response to that seen in the developing marsupial XY gonad [35], indicating a highly conserved role for estrogen in the initiation of the female developmental genes in mammals. The significant increase in WNT4 mRNA levels was consistent with a concomitant significant decrease in FGF9 expression. WNT4 and FGF9 are antagonistic signals in early gonad development, promoting ovarian and testicular fate respectively in the developing somatic cells [56]. This antagonistic relationship is conserved across humans, mice and marsupials [57]. WNT4 is also known to be upregulated by estrogen in the human uterus and rat brain [58, 59]. Similarly, Foxl2 is upregulated by estrogen in the adult mouse ovary [34] and is critical for ovarian development and the maintenance of granulosa cell identity [60].

Despite the clear induction of granulosa cell markers in NT2/D1 cells after $96 \mathrm{~h}$ of estrogen exposure, we also saw the reversion of SRY and SOX9 expression to control levels. Since these developmental programs are mutually exclusive in gonadal somatic cells [34, 61, 62], these data suggest a mixed response of cells in our culture system, with some cells heading towards a granulosa-like fate while others are reverting back to a Sertoli-like state. This is also supported by the variation seen in our colocalisation results at $96 \mathrm{~h}$, which shows that despite SOX9 mRNA levels returning to control levels after $96 \mathrm{~h}$, there is still significantly more protein in the cytoplasm of the estrogen exposed cells. This reflects what is observed in a biological context, where the presence of paracrine factors (FGF9 and PGD2) promotes recruitment of neighboring cells to Sertoli cell fate and away from a granulosa cell fate [63, 64]. These results are also in line with what is observed in humans, where exposure to exogenous oestrogen negatively impacts male gonad development and fertility but does not cause complete sex reversal [12].

Cells treated for $96 \mathrm{~h}$ with the high concentration of estrogen also showed an increase in $A M H$ expression, although this was not significant. While AMH is a direct downstream target of SOX9 in Sertoli cells, it is also expressed in granulosa cells, where it has a role in supporting folliculogenesis $[65,66] . A M H$ is upregulated in response to estrogen in mature granulosa cells [67], unlike in Sertoli cells where estrogen suppresses its transcription [this study, 35]. It is possible that as NT2/D1 cells transition towards a female fate after prolonged estrogen exposure, that $\mathrm{AMH}$ is positively responding to estrogen as it would in a normal female somatic cell. This interesting result could suggest estrogen is not only impacting its direct transcriptional targets but is also altering the regulatory landscape within cells.

\section{Conclusions}

Together, our data demonstrate that estrogen can alter the bioavailability of SOX9 within NT2/D1 cells to cause a suppression of the testis developmental program and promote transcription of key ovarian genes in a human testis-derived cell line (Fig. 6). These results are consistent with the known impacts of estrogen on the developing gonads in marsupials [21, 22, 35], indicating that estrogen may have a conserved role in mediating somatic cell fate across mammals. Furthermore, they implicate a role for estrogen in reinforcing the balance between female and male factors that maintain somatic cell fate in the gonad. This has broad implications for interpreting the potential effects of estrogenic endocrine disruptors on human development. We propose that the cytoplasmic retention of SOX9 is a potential mechanism for how estrogenic endocrine disruptors may be impacting Sertoli cells and testis development. Even a brief, reversible disruption to Sertoli cell function in the developing male fetus could have impacts on the patterning of the adult testis. The effects we have observed are significant but subtle in magnitude. This is consistent with the impacts of EDCs on humans where estrogen exposures cause morphological disruptions to the testis but not complete sex reversal in adult men [12]. Given the widespread exposures to estrogenic EDCs and the rapid increase in DSDs in humans, this effect of estrogen furthers our understanding about how such chemicals could be contributing to the overall decrease in male fertility and reproductive health.

\section{Methods \\ Cell culture and estrogen treatment}

The human testis-derived embryonal carcinoma NTERA-2 clone D1 [NT2/D1] (cells were purchased from ATCC.org; ATCC CRL-1973) cell line shares many properties with Sertoli cells. They express SOX9, show activation of SOX9 target genes, suppression of female markers, and endogenously express estrogen receptors $[41,42]$. The cells were maintained at $37^{\circ} \mathrm{C}, 5 \% \mathrm{CO}_{2}$ in phenol red free Dulbeccos Modified Eagles Medium (to avoid the estrogenic effect of phenol red in culture [68]) supplemented with 10\% fetal bovine serum (Gibco) and antibiotic-antimycotic (Gibco). Cells were either cultured on Nunc Lab-Tek Chamber slides (immunofluorescence experiments) or 6-well plates (qPCR experiments). Cells were treated with $17 \alpha$-ethynylestradiol (EE2; Sigma Aldrich) dissolved in ethanol, for $48 \mathrm{~h}$ or $96 \mathrm{~h}$ at either 10 

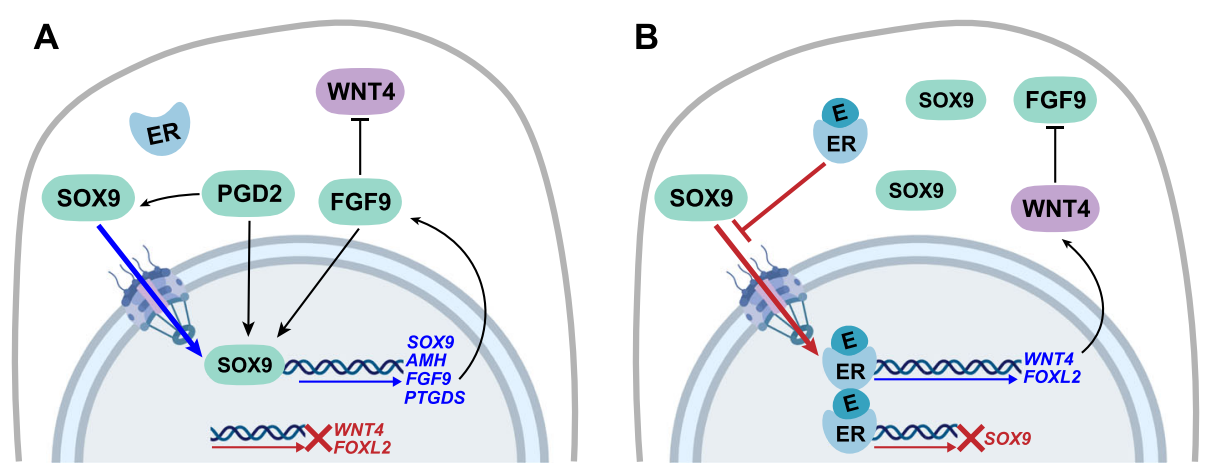

Fig. 6 Model for estrogen regulation of SOX9 in Sertoli cells. a In a normal Sertoli cell SOX9 increases expression of itself and its downstream targets AMH, FGF9, PTGDS by translocating from the cytoplasm to the nucleus. PGD2 facilitates the nuclear entry of SOX9, while FGF9 inhibits WNT4 and there is no expression of FOXL2. $\mathbf{b}$ Exogenous estrogen (E) blocks SOX9 nuclear entry, increasing the amount of SOX9 in the cytoplasm and preventing activation of downstream SOX9 targets. Activated estrogen receptors (ERs) repress SOX 9 transcription and promote expression of WNT4 and FOXL2. WNT4 subsequently inhibits FGF9

$\mathrm{nM}$ or $100 \mathrm{nM}$. EE2 was chosen due to its longer halflife in culture and its biological relevance given its widespread use and pervasiveness in our environment [69, 70]. The final concentration of ethanol added to culture was $<0.05 \%$. An identical amount of ethanol was added to control cells, which were grown in the absence of estrogen.

\section{Immunofluorescence}

Cells were fixed in $4 \%$ paraformaldehyde in phosphate buffered saline (PBS) for $10 \mathrm{~min}$ at $4{ }^{\circ} \mathrm{C}$. Fixed cells were exposed to a one-hour blocking step in 10\% horse serum in $0.1 \%$ TritonX in PBS, before being stained with antiSOX9 (ab5535; Millipore; 1:500) or anti-ER $\alpha$ (ab37438; Abcam; 1:500) and the nuclear marker DAPI (4',6-diamidino-2-phenylindole in Fluoroshield mounting medium; ab104139; Abcam). SOX9 and ER $\alpha$ were visualized using Alexa-Fluor 555 anti-rabbit secondary antibody (A21428; Invitrogen; 1:500). Images were captured on a Nikon A1R confocal. At least five images from each individual culture within a treatment group were randomly chosen for analysis of SOX9. Using Image J software, we calculated Manders' coefficient to determine the percentage of cytoplasmic SOX9. Mann-Whitney U tests were used to compare the percentage of cytoplasmic SOX9 between control and treated cells.

\section{RNA extraction, RT-PCR, and qPCR}

RNA was extracted from NT2/D1 cells using the GenElute Mammalian Total RNA Miniprep Kit (Sigma Aldrich) as per the manufacturer's instructions. Total RNA was DNase treated using Turbo DNA free (Ambion) as per the manufacturer's instructions. Complementary DNA was produced using the Superscript III First Strand Synthesis System for reverse transcriptase (RT)PCR (Invitrogen) according to the manufacturer's instructions. Quantitative PCR was carried out on a Stratagene MX3000P system, using Quantitect SYBR Green PCR Master Mix (Qiagen) at $55^{\circ} \mathrm{C}$ annealing temperature. mRNA levels of $S O X 9$, SRY, AMH, FGF9, PTGDS, FOXL2, and WNT4 were normalized against reference genes $C H M P 2 A$ or TBP using the method described by Pfaffl [71]. Primer sequences used are provided in supplementary materials Table 1 . Expression levels in control cell culture were designated as 1 and expression of each gene in the corresponding estrogen treated culture was expressed relative to control levels. Standard t-tests were used to determine any significant differences in gene expression between control and treated cells.

\section{Supplementary information}

Supplementary information accompanies this paper at https://doi.org/10. 1186/s12860-020-00307-9.

Additional file 1

\section{Abbreviations}

EDCs: Endocrine disrupting chemicals; DSDs: Differences of sexual development; NT2/D1: NTERA-2 clone D1; EE2: 17a-ethynylestradiol; SOX9: SRY-box transcription factor 9; AMH: Anti-mullerian hormone; FGF9: Fibroblast growth factor 9; PTGDS: Prostaglandin D synthase: WNT4: WNT family member 4; FOXL2: Forkhead box L2; ERa: Estrogen receptor a

\section{Acknowledgements}

Thank you to Jack Scanlan (University of Melbourne) for his assistance with figure design.

\section{Authors' contributions}

MKS conducted all experiments and analysed the data. MKS, DMM and AJP conceived the study and wrote the manuscript. All authors read and approved the manuscript 


\section{Funding}

This work was supported by an NHMRC Project Grant APP1142481 to AJP. The funding body played no role in the design of the study and collection, analysis, interpretation of data or in writing the manuscript.

\section{Availability of data and materials}

All data generated or analysed during this study are included in this published article and its supplementary information files.

\section{Ethics approval and consent to participate}

Not applicable for cell line work.

\section{Consent for publication}

Not applicable.

\section{Competing interests}

The authors declare that they have no competing interests.

Received: 25 March 2020 Accepted: 25 August 2020 Published online: 15 September 2020

\section{References}

1. Lee PA, Nordenström A, Houk CP, Ahmed SF, Auchus R, Baratz A, et al. Global disorders of sex development update since 2006: perceptions, approach and care. Horm Res Paediatr. 2016;85:158-80.

2. Nassar N, Bower C, Barker A. Increasing prevalence of hypospadias in Western Australia, 1980-2000. Arch Dis Child. 2007;92:580-4.

3. Paulozzi LJ. International trends in rates of hypospadias and cryptorchidism. Environ Health Perspect. 1999:107:297-302.

4. Levine $H$, Jørgensen N, Martino-Andrade A, Mendiola J, Weksler-Derri D, Mindlis I, et al. Temporal trends in sperm count: a systematic review and meta-regression analysis. Hum Reprod Update. 2017;23:646-59.

5. Kalfa N, Paris F, Philibert P, Orsini M, Broussous S, Fauconnet-Servant N, et al. Is hypospadias associated with prenatal exposure to endocrine disruptors? A French collaborative controlled study of a cohort of 300 consecutive children without genetic defect. Eur Urol. 2015;68:1023-30.

6. Morales-Suárez-Varela MM, Toft GV, Jensen MS, Ramlau-Hansen C, Kaerlev L, Thulstrup A-M, et al. Parental occupational exposure to endocrine disrupting chemicals and male genital malformations: a study in the Danish National Birth Cohort study. Environ Health. 2011;10:3.

7. Fisher JS. Environmental anti-androgens and male reproductive health: focus on phthalates and testicular dysgenesis syndrome. Reproduction. 2004; 127:305-15.

8. Skakkebaek NE, Rajpert-De Meyts E, Buck Louis GM, Toppari J, Andersson AM, Eisenberg ML, et al. Male reproductive disorders and fertility trends: influences of environment and genetic susceptibility. Physiol Rev. 2015;96: 55-97.

9. Winston JJ, Emch M, Meyer RE, Langlois P, Weyer P, Mosley B, et al. Hypospadias and maternal exposure to atrazine via drinking water in the National Birth Defects Prevention study. Environ Health. 2016;15:76.

10. Giordano F, Abballe A, De Felip E, di Domenico A, Ferro F, Grammatico P, et al. Maternal exposures to endocrine disrupting chemicals and hypospadias in offspring. Birth Defects Res Part A Clin Mol Teratol. 2010;88: 241-50

11. Diamanti-Kandarakis E, Bourguignon JP, Giudice LC, Hauser R, Prins GS, Soto AM, et al. Endocrine-disrupting chemicals: an Endocrine Society scientific statement. Endocr Rev. 2009:30:293-342.

12. Leavy M, Trottmann M, Liedl B, Reese S, Stief C, Freitag B, et al. Effects of elevated $\beta$-estradiol levels on the functional morphology of the testis - new insights. Sci Rep. 2017;7:39931.

13. Govers LC, Phillips TR, Mattiske DM, Rashoo N, Black JR, Sinclair A, et al. A critical role for estrogen signaling in penis development. FASEB J. 2019;33: 10383-92

14. Cripps SM, Mattiske DM, Black JR, Risbridger GP, Govers LC, Phillips TR, et al. A loss of estrogen signaling in the aromatase deficient mouse penis results in mild hypospadias. Differentiation. 2019;109:42-52.

15. Zambrano E, Guzmán C, Rodríguez-González GL, Durand-Carbajal M, Nathanielsz PW. Fetal programming of sexual development and reproductive function. Mol Cell Endocrinol. 2014;382:538-49.
16. Ramsey M, Crews D. Steroid signaling and temperature-dependent sex determination - reviewing the evidence for early action of estrogen during ovarian determination in turtles. Semin Cell Dev Biol. 2009;20:283-92.

17. Pannetier M, Mandon-Pepin B, Copelli S, Fellous M. Molecular aspects of female and male gonadal development in mammals. Pediatr Endocrinol Rev. 2004;1:274-87.

18. Payen E, Pailhoux E, Abou Merhi R, Gianquinto L, Kirszenbaum M, Locatelli A, et al. Characterization of ovine SRY transcript and developmental expression of genes involved in sexual differentiation. Int J Dev Biol. 1996;40:567-75.

19. Juengel JL, Heath DA, Quirke LD, McNatty KP. Oestrogen receptor alpha and beta, androgen receptor and progesterone receptor mRNA and protein localisation within the developing ovary and in small growing follicles of sheep. Reproduction. 2006:131:81-92.

20. Garverick HA, Juengel JL, Smith P, Heath DA, Burkhart MN, Perry GA, et al. Development of the ovary and ontongeny of mRNA and protein for P450 aromatase (arom) and estrogen receptors (ER) a and $\beta$ during early fetal life in cattle. Anim Reprod Sci. 2010;117:24-33.

21. Burns RK. Experimental reversal of sex in the gonads of the opossum didelphis virginiana. Proc Natl Acad Sci U S A. 1955;41:669-76.

22. Coveney D, Shaw G, Renfree MB. Estrogen-induced gonadal sex reversal in the tammar wallaby. Biol Reprod. 2001;65:613-21.

23. Lemmen JG, Broekhof JL, Kuiper GG, Gustafsson JA, van der Saag PT, van der Burg B. Expression of estrogen receptor alpha and beta during mouse embryogenesis. Mech Dev. 1999;81:163-7.

24. Fowler PA, Anderson RA, Saunders PT, Kinnell H, Mason Jl, Evans DB, et al. Development of steroid signaling pathways during primordial follicle formation in the human fetal ovary. J Clin Endocrinol Metab. 2011;96:1754-62.

25. Fietz D, Ratzenböck C, Hartmann K, Raabe O, Kliesch S, Weidner W, et al. Expression pattern of estrogen receptors $\alpha$ and $\beta$ and $\mathrm{G}$-protein-coupled estrogen receptor 1 in the human testis. Histochem Cell Biol. 2014;142:421-32.

26. George FW, Wilson JD. Conversion of androgen to estrogen by the human fetal ovary. J Clin Endocrinol Metab. 1978:47:550-5.

27. Britt KL, Drummond AE, Dyson M, Wreford NG, Jones MEE, Simpson ER, et al. The ovarian phenotype of the aromatase knockout (ArKO) mouse. J Steroid Biochem Mol Biol. 2001;79:181-5.

28. Britt KL, Findlay JK. Regulation of the phenotype of ovarian somatic cells by estrogen. Mol Cell Endocrinol. 2003;202:11-7.

29. Sinclair AH, Berta P, Palmer MS, Hawkins JR, Griffiths BL, Smith MJ, et al. A gene from the human sex-determining region encodes a protein with homology to a conserved DNA-binding motif. Nature. 1990;346:240-4.

30. Morais da Silva S, Hacker A, Harley V, Goodfellow P, Swain A, Lovell-Badge R. Sox9 expression during gonadal development implies a conserved role for the gene in testis differentiation in mammals and birds. Nat Genet. 1996;14: 62-8.

31. Knower KC, Kelly S, Harley VR. Turning on the male - SRY, SOX9 and sex determination in mammals. Cytogenet Genome Res. 2003;101:185-98

32. Liu CF, Bingham N, Parker K, Yao HHC. Sex-specific roles of beta-catenin in mouse gonadal development. Hum Mol Gen. 2008;18:405-17.

33. Vainio S, Heikkilä M, Kispert A, Chin N, McMahon AP. Female development in mammals is regulated by Wnt-4 signalling. Nature. 1999;397:405-9.

34. Uhlenhaut NH, Jakob S, Anlag K, Eisenberger T, Sekido R, Kress J, et al. Somatic sex reprogramming of adult ovaries to testes by FOXL2 ablation. Cell. 2009;139:1130-42

35. Pask AJ, Calatayud NE, Shaw G, Wood WM, Renfree MB. Oestrogen blocks the nuclear entry of SOX9 in the developing gonad of a marsupial mammal. BMC Biol. 2010:8:113-23.

36. Sim H, Argentaro A, Harley VR. Boys, girls and shuttling of SRY and SOX9. Trends Endocrinol Metab. 2008;19:213-22.

37. Malki S, Boizet-Bonhoure B, Poulat F. Shuttling of SOX proteins. Int J Biochem Cell Biol. 2010:42:411-6.

38. Argentaro A, Sim H, Kelly S, Preiss S, Clayton A, Jans DA, et al. A SOX9 defect of calmodulin-dependent nuclear import in campomelic dysplasia/ autosomal sex reversal. J Biol Chem. 2003;278:33839-47.

39. Trukhina AV, Lukina NA, Wackerow-Kouzova ND, Smirnov AF. The variety of vertebrate mechanisms of sex determination. Biomed Res Int. 2013;2013: 587460

40. Qin Y, Bishop CE. Sox9 is sufficient for functional testis development producing fertile male mice in the absence of Sry. Hum Mol Genet. 2005;14:1221-9.

41. Knower KC, Sim H, McClive PJ, Bowles J, Koopman P, Sinclair AH, et al. Characterisation of urogenital ridge gene expression in the human embryonal carcinoma cell line NT2/D1. Sex Dev. 2007;1:114-26. 
42. Knower KC, Kelly S, Ludbrook LM, Bagheri-Fam S, Sim H, Bernard P, et al. Failure of SOX9 regulation in 46XY disorders of sex development with SRY, SOX9 and SF1 mutations. PLOS One. 2011;6:e17751.

43. Malki S, Berta P, Poulat F, Boizet-Bonhoure B. Cytoplasmic retention of the sex-determining factor SOX9 via the microtubule network. Exp Cell Res. 2005;309:468-75.

44. Malki S, Nef S, Notarnicola C, Thevenet L, Mejean C, Berta P, et al. Prostaglandin D2 induces nuclear import of the sex-determining factor SOX9 via its CAMP-PKA phosphorylation. EMBO J. 2005;24:1798-809.

45. de Santa Barbara P, Bonneaud N, Boizet B, Desclozeaux M, Moniot B Sudbeck $P$, et al. Direct interaction of SRY-related protein SOX9 and steroidogenic factor 1 regulates transcription of the human anti-Müllerian hormone gene. Mol Cell Biol. 1998;18:6653-65.

46. Moniot B, Declosmenil F, Barrionuevo F, Scherer G, Aritake K, MALKI S, et al. The PGD2 pathway, independently of FGF9, amplifies SOX9 activity in Sertoli cells during male sexual differentiation. Development. 2009;136: 1813-21.

47. Bernard P, Sim H, Knower K, Vilain E, Harley V. Human SRY inhibits $\beta$ catenin-mediated transcription. Int J Biochem Cell Biol. 2008;40:2889-900.

48. Thevenet L, Méjean C, Moniot B, Bonneaud N, Galéotti N, Aldrian-Herrada G, et al. Regulation of human SRY subcellular distribution by its acetylation/ deacetylation. EMBO J. 2004;23:3336-45.

49. Loke J, Pearlman A, Radi O, Zuffardi O, Giussani U, Pallotta R, et al. Mutations in MAP 3K1 tilt the balance from SOX9/FGF9 to WNT/betacatenin signaling. Hum Mol Genet. 2014;23:1073-83.

50. Klinge CM. Estrogen receptor interaction with estrogen response elements. Nucleic Acids Res. 2001;29:2905-19.

51. Cameron FJ, Hageman RM, Cooke-Yarborough C, Kwok C, Goodwin LL, Sillence DO, et al. A novel germ line mutation in SOX9 causes familial campomelic dysplasia and sex reversal. Hum Mol Genet. 1996:5:1625-30.

52. Josso N, Cate RL, Picard JY, Vigier B, di Clemente N, Wilson C, et al. Antimüllerian hormone: the Jost factor. Recent Prog Horm Res. 1993;48:1-59.

53. Wilhelm D, Hiramatsu R, Mizusaki H, Widjaja L, Combes AN, Kanai Y, et al. SOX9 regulates prostaglandin $D$ synthase gene transcription in vivo to ensure testis development. J Biol Chem. 2007;282:10553-60.

54. Rossitto M, Ujjan S, Poulat F, Boizet-Bonhoure B. Multiple roles of the prostaglandin D2 signaling pathway in reproduction. Reproduction. 2014; 149:R49-58.

55. Colvin JS, Green RP, Schmahl J, Capel B, Ornitz DM. Male-to-female sex reversal in mice lacking fibroblast growth factor 9. Cell. 2001;104:875-89.

56. Kim Y, Kobayashi A, Sekido R, DiNapoli L, Brennan J, Chaboissier M-C, et al. Fgf9 and Wnt4 act as antagonistic signals to regulate mammalian sex determination. Hamada H, editor. PLoS Biol. 2006:4:e187-11.

57. Chung JW, Pask AJ, Yu H, Renfree MB. Fibroblast growth factor-9 in marsupial testicular development. Sex Dev. 2011;5:131-40.

58. Kaya Okur HS, Das A, Taylor RN, Bagchi IC, Bagchi MK. Roles of estrogen receptor- $a$ and the coactivator MED1 during human endometrial decidualization. Mol Endocrinol. 2016;30:302-13.

59. Miyakoshi T, Kajiya H, Miyajima K, Takei M, Tobita M, Takekoshi S, et al. The expression of Wnt4 is regulated by estrogen via an estrogen receptor alpha-dependent pathway in rat pituitary growth hormone-producing cells. Acta Histochem Cytochem. 2009;42:205-13.

60. Ottolenghi C, Omari S, Garcia-Ortiz JE, Uda M, Crisponi L, Forabosco A, et al. Foxl2 is required for commitment to ovary differentiation. Hum Mol Genet. 2005;14:2053-62

61. Brennan J, Capel B. One tissue, two fates: molecular genetic events that underlie testis versus ovary development. Nat Rev Genet. 2004;5:509-21.

62. Matson CK, Murphy MW, Sarver AL, Griswold MD, Bardwell VJ, Zarkower D. DMRT1 prevents female reprogramming in the postnatal mammalian testis. Nature. 2011;476:101-4.

63. Wilhelm D, Martinson F, Bradford S, Wilson M, Combes AN, Beverdam A, et al. Sertoli cell differentiation is induced both cell-autonomously and through prostaglandin signaling during mammalian sex determination. Dev Biol. 2005;287:111-24.

64. Kim Y, Capel B. Balancing the bipotential gonad between alternative organ fates: a new perspective on an old problem. Dev Dyn. 2006;235:2292-300.

65. Weenen C, Laven JSE, Bergh Von ARM, Cranfield M, Groome NP, Visser JA, et al. Anti-Müllerian hormone expression pattern in the human ovary: potential implications for initial and cyclic follicle recruitment. Mol Hum Reprod. 2004;10:77-83.

66. Rajpert-De Meyts E, Jorgensen N, Graem N, Muller J, Cate RL, Skakkebaek NE. Expression of anti-Mullerian hormone during normal and pathological gonadal development: association with differentiation of Sertoli and granulosa cells. J Clin Endocrinol Metab. 1999;84:3836-44.

67. Grynberg M, Pierre A, Rey R, Leclerc A, Arouche N, Hesters L, et al. Differential regulation of ovarian anti-müllerian hormone $(\mathrm{AMH})$ by estradiol through $\alpha$ - and $\beta$-estrogen receptors. J Clin Endocrinol Metab. 2012;97: E1649-57.

68. Welshons WV, Wolf MF, Murphy CS, Jordan VC. Estrogenic activity of phenol red. Mol Cell Endocrinol. 1988;57:169-78.

69. Adeel M, Song X, Wang Y, Francis D, Yang Y. Environmental impact of estrogens on human, animal and plant life: a critical review. Environ Int. 2017:99:107-19.

70. Aris AZ, Shamsuddin AS, Praveena SM. Occurrence of 17a-ethynylestradiol (EE2) in the environment and effect on exposed biota: a review. Environ Int. 2014;69:104-19.

71. Pfaffl MW. A new mathematical model for relative quantification in real-time RT-PCR. Nucleic Acids Res. 2001;29:e45.

\section{Publisher's Note}

Springer Nature remains neutral with regard to jurisdictional claims in published maps and institutional affiliations.
Ready to submit your research? Choose BMC and benefit from:

- fast, convenient online submission

- thorough peer review by experienced researchers in your field

- rapid publication on acceptance

- support for research data, including large and complex data types

- gold Open Access which fosters wider collaboration and increased citations

- maximum visibility for your research: over $100 \mathrm{M}$ website views per year

At $\mathrm{BMC}$, research is always in progress.

Learn more biomedcentral.com/submissions 